\title{
Effect of growth hormone replacement therapy in a boy with Dent's disease: a case report
}

Mira Samardzic ${ }^{1 *}$, Snezana Pavicevic ${ }^{1}$, Michael Ludwig $^{2}$ and Radovan Bogdanovic ${ }^{3}$

\begin{abstract}
Introduction: Dent's disease is an X-linked recessive proximal tubulopathy characterized by low molecular weight proteinuria, hypercalciuria, nephrocalcinosis, nephrolithiasis and progressive renal failure. To the best of our knowledge, this is only the third report on the use of growth hormone therapy in a child with poor growth associated with Dent's disease.
\end{abstract}

Case presentation: We report on a 7-year-old Montenegrin boy with proteinuria, hypercalciuria, nephrocalcinosis, rickets and short stature with unimpaired growth hormone secretion. A molecular genetic analysis showed S244L substitution on the CLCN5 gene. After two years of conventional treatment with hydrochlorothiazide, laboratory tests revealed more prominent proteinuria, mild hypophosphatemia, increased values of alkaline phosphatase and features of rickets. Phosphate salts, calcitriol, potassium citrate and growth hormone were included in the therapy. After three years of therapy, his adjusted parental stature was 1.53 standard deviations higher than at the initiation of growth hormone therapy. His global kidney functions and levels of proteinuria and calciuria remained relatively stable. In spite of the growth hormone therapy, his tubular reabsorption of phosphate deteriorated.

Conclusion: Treatment with recombinant human growth hormone may have a positive effect on final height in poorly growing children with Dent's disease and hypophosphatemic rickets. However, it is not possible to reach definite conclusions due to the small sample within the literature and the brief duration of the therapy.

\section{Introduction}

Dent's disease is an X-linked recessive proximal tubulopathy characterized by low molecular weight proteinuria, hypercalciuria, nephrocalcinosis, nephrolithiasis, and slowly progressive renal failure in affected males. Renal acidification abnormalities are only rarely seen in Dent's disease, whereas the hypokalemic metabolic alkalosis associated with hyperreninemic hyperaldosteronism (Bartter-like syndrome) has been reported in a few patients [1]. Clinical characteristics of Dent's disease include familial tubular syndromes such as X-linked recessive nephrolithiasis, $\mathrm{X}$-linked recessive hypophosphatemic rickets and low-molecular weight proteinuria with hypercalciuria and nephrocalcinosis in Japanese children [2]. Dent's disease is caused by mutations in the CLCN5 gene, which is located on the short arm of the $\times$ chromosome $(\mathrm{Xp11.22).}$ The CLCN5 gene

\footnotetext{
* Correspondence: samardzic@t-com.me

'Institute for Sick Children, Department of Endocrinology and Nephrology, Ljubljanska bb, 20000 Podgorica, Montenegro

Full list of author information is available at the end of the article
}

encodes for the 746 amino-acid CLC-5 chloride channel that belongs to the voltage-gated chloride channel family (CLC-7, CLC-Ka and CLC-Kb) implicated in membrane excitability, transepithelial transport and possibly the regulation of cell volume [3]. The mechanism by which CLC-5 dysfunction results in hypercalciuria and the other features of Dent's disease remains unclear.

The different clinical features of Dent's disease makes treatment complex, and it requires simultaneous monitoring of the effects of therapy. There is still no clear strategy for the management of patients with this condition. Thiazide diuretics have been used to reduce urinary calcium excretion, and to prevent the recurrence of nephrolithiasis [4]. A high citrate diet preserved the renal function and delayed the progression of renal disease in CLC-5 knockout mice [5]. Rickets was a prominent feature in about one third of patients reported with Dent's disease. The recommended treatment is based on oral phosphate salts and calcitriol [6].

\section{Biomed Central}

(c) 2011 Samardzic et al; licensee BioMed Central Ltd. This is an Open Access article distributed under the terms of the Creative Commons Attribution License (http://creativecommons.org/licenses/by/2.0), which permits unrestricted use, distribution, and reproduction in any medium, provided the original work is properly cited. 


\section{Case presentation}

A 7-year-old Montenegrin boy was initially referred to the pediatric endocrinology ward because of short stature. His height was 2.93 standard deviations (SD) below the mean. His mid-parental height was $181.6 \mathrm{~cm}(+1$ SD). Our patient was born at term following an uneventful pregnancy with a birth weight of $3.95 \mathrm{~kg}$ and a birth length of $57 \mathrm{~cm}$. His family history was negative for short stature, delayed puberty and renal disease. Except for dental caries, high palate and slight genus valgus, he had no other abnormalities. His blood pressure was normal and his bone age was 5 years. A laboratory test was positive for proteinuria. He had an elevated urinary calcium level and $\beta 2$-microglobulin excretion. A renal ultrasound showed early medullary nephrocalcinosis. His levels of serum calcium, phosphorus and alkaline phosphatase were normal. His tubular reabsorption of phosphate (TRP) was decreased. His creatinine clearance test [7] was normal $(92.8 \mathrm{ml} / \mathrm{min} /$ $1.73 \mathrm{~m}^{2}$ ). No other electrolyte or metabolic abnormalities were observed. His overnight growth hormone $(\mathrm{GH})$ profiles were normal ( $>3$ peaks of $>10 \mu \mathrm{g} / \mathrm{L}$ ). An audiometry test was also unremarkable. In order to confirm a diagnosis of Dent's disease, molecular genetic analysis was performed one year later and showed a mutation in the CLCN5 gene, leading to S244L amino acid substitution. The mutation carrier, the patient's mother, was asymptomatic with slight hypercalciuria.

After two years of conventional treatment with hydrochlorothiazide, our patient was referred for a new endocrine evaluation because of a failure to catch-up growth. Laboratory tests showed more prominent urinary protein excretion, whereas the level of calciuria remained unchanged. Clinical, radiological and laboratory signs of hypophosphatemic rickets became noticeable. We found hypophosphatemia $(0.74 \mathrm{mmol} / \mathrm{L})$, elevated serum alkaline phosphatase activity (926 U/L), and a nearly normal level of parathyroid hormone. X-rays showed enlargement of his wrists and knees and fraying of the metaphyses of his distal ulna and radius. Our patient's growth velocity was $4.7 \mathrm{~cm} / \mathrm{yr}(-1 \mathrm{SD})$. His parental adjusted height at that time was -3.11 SD; his pubertal status was Tanner stage one. A height prediction based on his recent growth was approximately $160.7 \mathrm{~cm}$ (Statistical program: SAS v9.13). At the age of nine years and three months we initiated recombinant human growth hormone (rhGH) therapy. The indication for GH therapy was markedly short stature and chronic renal disease stage one [8]. The average dose of rhGH was $0.04-0.05 \mathrm{mg} / \mathrm{kg}$ per day. Because of the overt hypophosphatemic rickets and hypercalciuria, in addition to hydrochlorothiazide we started him on calcitriol 20-40 $\mathrm{ng} / \mathrm{kg} /$ day in two divided doses, phosphorus $20-40 \mathrm{mg} /$ $\mathrm{kg} /$ day, maximum $2.5 \mathrm{~g} /$ day in 3-5 divided doses and potassium citrate. A follow-up was performed at threemonth intervals. We followed his growth velocity, serum phosphate, serum creatinine, creatinine clearance, TRP, protein and calcium excretion, insulin-like growth factor 1(IGF-1), insulin-like growth factor-binding protein 3 (IGFBP-3) and other laboratory tests in relation to growth hormone therapy (Table 1, Table 2). In the first two years, our patient grew at an average rate of $9 \mathrm{~cm}$ per year (>95c), and in the third year he grew $6 \mathrm{~cm}$ (50c) (Figure 1). His bone age remained retarded. During rhGH treatment and other therapies, there were no relevant changes in his creatinine clearance or the degree of nephrocalcinosis on renal ultrasonograms. His cystatin C level was also normal at $-0.85 \mathrm{mg} / \mathrm{L}$ (normal range $0.53-0.95 \mathrm{mg} / \mathrm{L}$ ). His level of proteinuria remained stable whilst urinary calcium excretion was reduced. Despite continued phosphaturia, his serum phosphate level increased gradually, and his serum alkaline phosphatase returned to normal. No acceleration in bone age or increase in glucose intolerance was noted. After suspending GH therapy for two months, GH secretion was re-evaluated: IGF-1 level was under the normal range and a clonidine stimulation test showed a peak serum $\mathrm{GH}$ concentration of $16.5 \mu \mathrm{g} / \mathrm{l}$, again confirming the absence of a GH deficiency.

\section{Discussion}

Dent's disease is an inherited tubulopathy caused by CLCN5 gene mutations. To date, more than 80 distinct CLCN5 mutations have been reported [9]. S244, is the most common mutation in CLCN5 thus far described. In our patient's family we also identified this mutation. Tosetto et al. found that approximately $48 \%$ of patients with Dent's disease had rickets, which correlates with only one mutation, S244L [10]. It is not completely clear how the loss of function in the endosomal chloride channel leads to a decrease in brush-border sodium/ inorganic phosphate co-transport. However, not all patients with Dent's disease show a decrease in phosphate reabsorption [9]. Hoopes et al., found that hypophosphatemic patients were not always affected by rickets. Also, some patients with Dent's disease have been observed to have extrarenal manifestations such as mild intellectual impairment, hypotonia and cataracts, and such patients have been reported to share a mutation in OCRL1 with the oculocerebrorenal syndrome of Lowe. The occurrence of these extrarenal manifestations with mutations relating to Lowe syndrome is referred as Dent's disease type 2 [11].

The most striking physical sign in the first described patient with Dent's disease and hypophosphatemic rickets was the shortness of stature [12]. At the time of setting the differential diagnosis our patient also had growth failure (-2.89 SD), although he had normal 
Table 1 Laboratory investigation before and after three years of combined conventional and GH replacement therapy

\begin{tabular}{|c|c|c|c|c|}
\hline & $24 \mathrm{mo}$ pre-GH & Baseline & 24 mo post-GH & $36 \mathrm{mo}$ post-GH \\
\hline & Hydrochlorothiazide & $\begin{array}{l}\text { Hydrochlorothiazide + } \\
\text { phosphate } \\
+ \text { K-citrate } \\
\text { +calcitriol+rhGH }\end{array}$ & $\begin{array}{l}\text { Hydrochlorothiazide + } \\
\text { phosphate } \\
\text { +K-citrate +calcitriol } \\
\text { +rhGH }\end{array}$ & $\begin{array}{l}\text { Hydrochlorothiazide + } \\
\text { phosphate } \\
\text { +K-citrate } \\
\text { +calcitriol+rhGH }\end{array}$ \\
\hline $\begin{array}{l}>2 \mathrm{GH} \text { peaks at night } \\
(\mathrm{nl}>20 \mathrm{mU} / \mathrm{L})\end{array}$ & $22.0-28.0$ & nd & nd & nd \\
\hline $\begin{array}{l}\text { GH peaks with provocative stimuli }(\mathrm{nl} \\
>20 \mathrm{mU} / \mathrm{L})\end{array}$ & nd & nd & nd & $\begin{array}{l}33 \\
\text { (2 mo without GH therapy) }\end{array}$ \\
\hline $\begin{array}{l}\text { IGF-1 } \\
(9 \mathrm{y}: \mathrm{nl} 123-275 \mathrm{ng} / \mathrm{ml}) \\
(11 \mathrm{y}: 139-395 \mathrm{ng} / \mathrm{ml}) \\
(12 \mathrm{y}: 143-693 \mathrm{ng} / \mathrm{ml})\end{array}$ & nd & $\begin{array}{l}122 \\
\text { (before GH therapy) }\end{array}$ & $\begin{array}{l}300.5-496 \\
\text { (with GH therapy) }\end{array}$ & $\begin{array}{l}\text { 90-125 } \\
\text { (2 mo without GH therapy) }\end{array}$ \\
\hline $\begin{array}{l}\text { Calcium (s) } \\
(\mathrm{nl} 2.1-2.5 \mathrm{mmol} / \mathrm{L})\end{array}$ & 2.4 & 2.4 & 2.4 & 2.3 \\
\hline $\begin{array}{l}\text { Phosphate }(\mathrm{s}) \\
\text { (nl 0.8-1.5 mmol/L) }\end{array}$ & 1.0 & 0.74 & 0.96 & $1-1.25$ \\
\hline $\begin{array}{l}\text { iPTH } \\
\text { (nl 0.95-5.7 pmol/l) }\end{array}$ & n.d & 6.1 & n.d & 2.68 \\
\hline $\begin{array}{l}\text { ALP (5-10 yr: 110-341 U/L) } \\
\text { (Puberty: < 500) }\end{array}$ & 224.70 & 926.0 & 638 & $160-174$ \\
\hline TRP (nl 85-98\%) & $65-77$ & 75 & 57 & $50-60$ \\
\hline $\begin{array}{l}\text { Creatinine clearance } \\
\left(\mathrm{nl} 89-165 \mathrm{ml} / \mathrm{min} / 1.73 \mathrm{~m}^{2}\right)\end{array}$ & 92.8 & 99.8 & 107 & 112.7 \\
\hline $\begin{array}{l}\beta 2 \text {-microglobulin } \\
(\mathrm{nl}<0.03-0.37 \mathrm{mg} / 24 \mathrm{~h})\end{array}$ & 81.6 & nd & nd & nd \\
\hline $\begin{array}{l}\text { Protein excretion } \\
(\mathrm{nl}<0.150 \mathrm{~g} / 24 \mathrm{~h})\end{array}$ & 1.86 & 3.21 & 2.1 & $2.0-3.0$ \\
\hline $\begin{array}{l}\text { Calcium excretion } \\
\text { (nl < } 4 \mathrm{mg} / \mathrm{kg} / 24 \mathrm{~h})\end{array}$ & 10.1 & 10.9 & 8.9 & $6.7-7.2$ \\
\hline
\end{tabular}

ALP: alkaline phosphatase; iPTH intact parathyroid hormone; nd: not determined; nl: normal level

global kidney functions. Sheffer-Babila et al. [13] studied the case of two brothers, 10 and 13 and a half years old, suffering from Dent's disease and GH deficiency, without symptoms of rickets. At the time of setting the diagnosis their growth retardation was -2.2 and -1.2 SD respectively. One brother had a diminished estimated glomerular filtration rate (GFR) (creatinine clearance: $68-83 \mathrm{ml} / \mathrm{min} / 1.73 \mathrm{~m}^{2}$ ); the other had normal estimated

Table 2 Anthropometric characteristics of rhGH-treated child with Dent's disease

\begin{tabular}{lllll}
\hline & $\begin{array}{l}\text { 24mo } \\
\text { pre-GH }\end{array}$ & Baseline & $\begin{array}{l}\text { 24 mo } \\
\text { post-GH }\end{array}$ & $\begin{array}{l}\text { 36 mo } \\
\text { post-GH }\end{array}$ \\
\hline Age (y) & 7.3 & 9.3 & 11.3 & 12.3 \\
\hline Bone age (y) & $44 / 12$ & 6 & 9 & 11 \\
\hline Height (cm) & 110.5 & 120.0 & 138 & 143.5 \\
\hline Height (SDS) & -2.89 & -2.93 & -1.83 & -1.4 \\
\hline Sitting height (cm) & 59 & 64 & 74 & 78 \\
\hline Sitting height/Leg length & 1.16 & 1.14 & 1.19 & 1.18 \\
\hline BMl (SDS) & $+1,26$ & +1.02 & +1.16 & +1.14 \\
\hline Parental adjusted height (SDS) & -3.08 & -3.11 & -2.02 & -1.58 \\
\hline
\end{tabular}

BMI: body mass index; SDS: standard deviation score
GFR (creatinine clearance: $101-143 \mathrm{ml} / \mathrm{min} / 1.73 \mathrm{~m}^{2}$ ). These patients were treated with enalapril, hydrochlorothiazide, calcitriol, phosphate supplements, vitamin E, vitamin $\mathrm{C}$, potassium citrate and growth hormone. Two years after initiating $\mathrm{GH}$ therapy their growth velocity was 8 and $10 \mathrm{~cm} / \mathrm{yr}$ respectively. In cases of short stature of various origins but without GH deficiency, such as Turner syndrome or short children born small for gestational age (SGA), the treatment used is rhGH. Not all patients with Dent's disease have GH deficiency, but reasons for treatment in our case were the presence of short stature and chronic renal disease [8]. In the first two years after starting our patient on $\mathrm{GH}$ and other therapies, the boy grew $9 \mathrm{~cm} / \mathrm{yr}$, and in the third year he grew $5.5 \mathrm{~cm}$. His IGF-1 levels were below normal range before treatment and increased to normal levels after treatment. The acceleration in growth velocity could be attributed to the increased concentration of circulating IGF-1, the increase in efficiency of food utilization with rhGH, and the conventional therapy for hypophosphatemic rickets. Pharmacologic treatment of $\mathrm{X}$-linked hypophosphatemia rickets leads to an improvement in the rickets, but effects on longitudinal growth 
Fig. 1. Growth chart of child with Dent's disease before and under additional therapy with rkGH

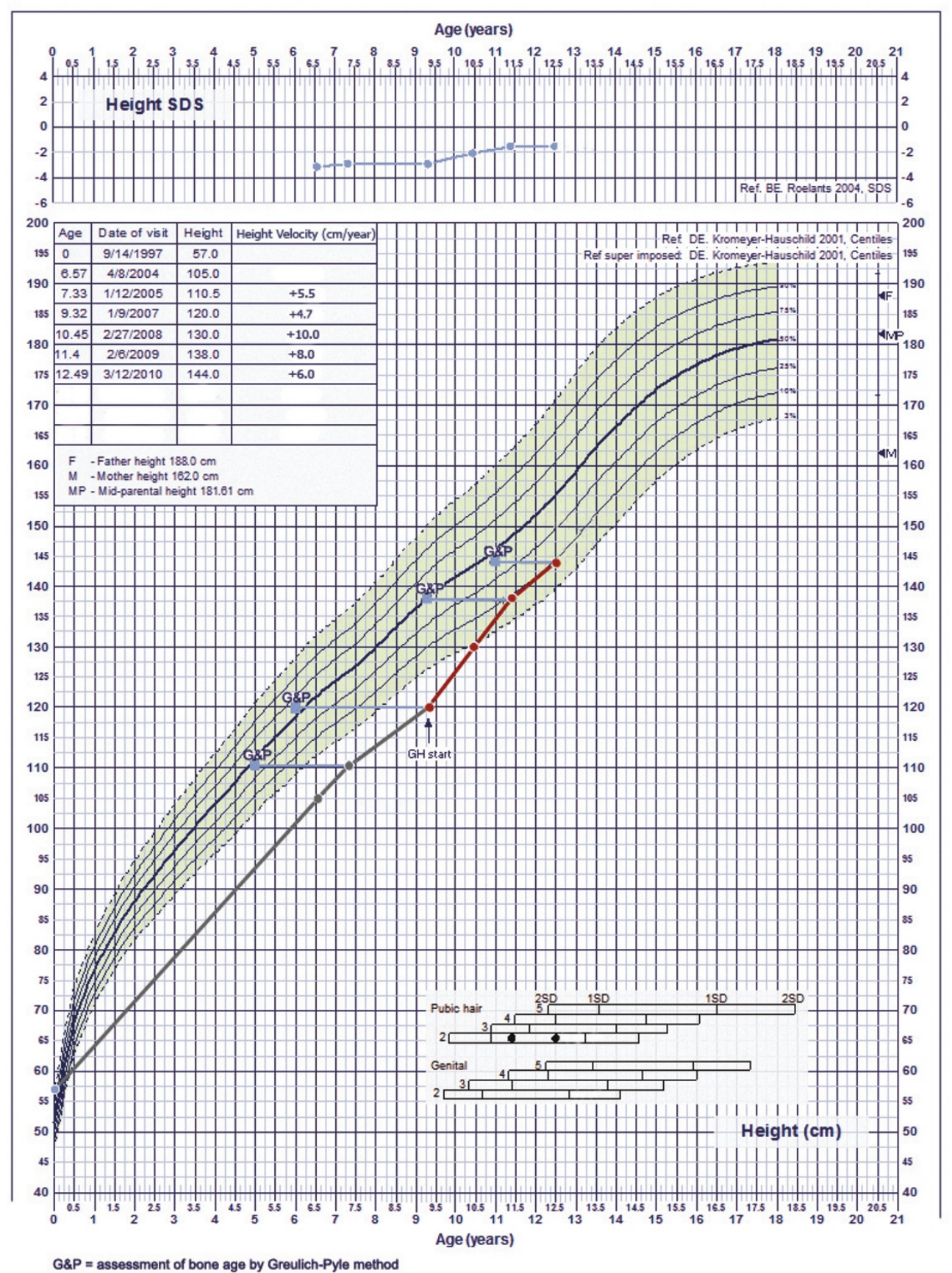

Figure 1 Growth chart of child with Dent's disease before and during additional therapy with rhGH. G\&P: assessment of bone age by Greulich-Pyle method.

and renal phosphate reabsorption are often disappointing [14].

Unlike in the case of the two brothers reported by Shaffer-Babila et al.[13], we did not observe an effect on renal phosphate reabsorption by rhGH treatment. It is well known that $\mathrm{GH}$, at least where mediated by IGF-1 (locally produced in the kidney), stimulates proximal tubular sodium/inorganic phosphate co-transport [15]. 
The growth of our patient was improved and proportional to his pubertal state. Since the therapy was started before the patient reached puberty it is not possible to estimate how the GH therapy will continue to affect our patient's final height. However after two years of therapy, growth started to slow down.

Although a correlation was found between renal function and growth impairment, significant short stature was seen at all levels of renal function. The etiology of growth delay in children with chronic kidney disease is multifactorial, including rickets, GH resistance, reduced $\mathrm{GH}$ secretion rate or greater loss of $\mathrm{GH}$, functional IGF deficiency and increased IGFBP -1,-2,-4 and -6 [16].

The aim of therapy in Dent's disease and hypophosphatemic rickets is to normalize serum alkaline phosphatase and achieve longitudinal growth. Conventional treatment with oral phosphate and calcitriol can heal rickets, but it does not always raise serum phosphate concentrations significantly, nor does it always normalize linear growth [12].

Both endogenous and exogenous $\mathrm{GH}$ result in an increase in GFR. It is likely that the increased GFR is mediated by IGF-1 [17]. It is of concern that long-term rhGH treatment could produce hyperfiltration with resultant glomerulosclerosis and an accelerated decline in renal function [18]. In our patient's case, GFR, measured as creatinine clearance at the beginning and at the end of monitoring, remained normal, but it increased from 92.8 to $112.7 \mathrm{ml} / \mathrm{min} / 1.73 \mathrm{~m}^{2}$. We were also concerned that rhGH might induce hypercalciuria during calcitriol treatment, however calcium excretion did not change significantly.

\section{Conclusion}

Effects of GH therapy in children with Dent's disease and short stature are positive, but it is difficult to reach conclusions because of the small sample size in the literature, the short duration of the therapy and the lack of a control group. Thus, further studies are needed to determinate the pathophysiological mechanism of rhGH action in Dent's disease.

\section{Consent}

Written informed consent was obtained from the patient's mother for publication of this case report and any accompanying images. A copy of the written consent is available for review by the Editor-in-Chief of this journal.

\section{Abbreviations}

GH: gGrowth hormone; GRF: glomerular filtration rate; IGF-1: insulin-like growth factor 1; IGFBP-3: insulin-like growth factor binding protein-3; SD: standard deviation; TRP: tubular reabsorption of phosphate; rhGH: recombinant human growth hormone.

\section{Acknowledgements}

This study was assessed and approved by the institutional review board and the letter of approval is available for examination.

\section{Author details}

${ }^{1}$ Institute for Sick Children, Department of Endocrinology and Nephrology, Ljubljanska bb, 20000 Podgorica, Montenegro. ${ }^{2}$ Department of Clinical Chemistry and Clinical Pharmacology, University of Bonn, Bonn, Germany. ${ }^{3}$ Institute for Mother and Child Health Care of Serbia, Department of Nephrology, Radoja Dakica 10, 11000 Belgrade, Serbia.

\section{Authors' contributions}

MS analyzed and interpreted the patient data regarding the endocrinological follow- up and was a major contributor in writing the manuscript. SP and RB performed nephrology management and consulted in the case. ML performed the molecular genetic analysis. All authors read and approved the final manuscript.

\section{Competing interests}

The authors declare that they have no competing interests.

Received: 28 December 2010 Accepted: 22 August 2011 Published: 22 August 2011

\section{References}

1. Bogdanovic R, Draaken M, Toromanovic A, Dordevic M, Stajic N, Ludwig M: A novel CLCN5 mutation in a boy with Bartter-like syndrome and partial growth hormone deficiency. Pediatr Nephrol 2010, 25(11):2363-2368.

2. Wrong OM, Norden AGW, Feest TG: Dent's Disease; a familial proximal renal tubular syndrome with low molecular weight proteinuria, hypercalciuria, nephrocalcinosis, metabolic bone disease, progressive renal failure and a marked male predominance. QJM 1994, 87(8):473-493.

3. Lloyd SE, Gunther W, Pearce SH, Thomson A, Bianchi ML, Bosio M, Craig IW, Fisher SE, Scheinman SJ, Wrong O, Jentsch TJ, Thakker RV: Characterisation of renal chloride channel, CLCN5, mutations in hypercalciuric nephrolithiasis (kidney stones) disorders. Hum Mol Genet 1997, 6(8):1233-1239.

4. Raja KA, Schurman S, D'mello RG, Blowey D, Goodyer P, Van Why S, PloutzSnyder RJ, Asplin J, Scheinman SJ: Responsiveness of hypercalciuria to thiazide in Dent's disease. J Am Soc Nephrol 2002, 13:2938-2944.

5. Cebotaru V, Kaul S, Devuyst O, Cai H, Recausen L, Guggino WB, Guggino SE: High citrate diet delays progression of renal insufficiency in the C1C-5 knockout mouse model of Dent's disease. Kidney Int 2005, 68:642-652.

6. Annigeri RA, Rajagoplan R: Hypophosphatemic rickets due to Dent's disease: a case report and review of literature. Indian J Nephrol 2009, 19:163-166.

7. Schwartz GJ, Work DF: Measurement and estimation of GFR in children and adolescents. Clin J Am Soc Nephrol 2009, 4(11):1832-1843.

8. Mahan JD, Warady BA, Consensus Committee: Assessment and treatment of short stature in pediatric patients with chronic kidney disease: a consensus statement. Pediatr Nephrol 2006, 21(7):917-930.

9. Ludwig M, Utsch B, Monnens L: Recent advances in understanding the clinical and genetic heterogeneity of Dent's disease. Nephrol Dial Transplant 2006, 21:2708-2717.

10. Tosetto E, Ghiggeri GM, Emma F, Barbano G, Carrea A, Vezzoli G, Torregrossa R, Cara M, Ripanti G, Ammenti A, Peruzzi L, Murer L, Ratsch IM, Citron L, Gambaro G, D'angelo A, Anglani F: Phenotypic and genetic heterogeneity in Dent's disease-the results of an Italian collaborative study. Nephrol Dial Transplant 2006, 21:2452-2463.

11. Shrimpton AE, Hoopes RR Jr, Knohl SJ, Hueber P, Reed AA, Christie PT, Igarashi T, Lee P, Lehman A, White C, Milford DV, Sanchez MR, Unwin R, Wrong OM, Thakker RV, Scheinman SJ: OCRL1 mutations in Dent 2 patients suggest a mechanism for phenotypic variability. Nephron Physiol 2009, 112(2):27-36

12. Dent $C E$, Friedman M: Hypercalciuric rickets associated with renal tubular damage. Arch Dis Child 1964, 39:240-249.

13. Sheffer-Babila S, Chandra M, Speiser PW: Growth hormone improves growth rate and preserves renal function in Dent disease. J Pediatr Endocrinol Metab 2008, 21:279-286. 
14. Haffner $D$, Nissel R, Wühl $E$, Mehls $O$ : Effects of growth hormone treatment on body proportions and final height among small children with X-linked hypophosphatemic rickets. Pediatrics 2004, 113(6):593-596.

15. Murer $\mathrm{H}$, Hernando N, Forster I, Biber J: Proximal tubular phosphate reabsorption: molecular mechanisms. Physiol Rev 2000, 80(4):1373-1409.

16. Mahesh S, Kaskel F: Growth hormone axis in chronic kidney disease. Pediatr Nephrol 2008, 23:41-48.

17. Hirschberg R, Kopple JDJ: The growth hormone-insulin-like growth factor I axis and renal glomerular function. J Am Soc Nephrol 1992, 2(9):1417-1422.

18. el Nahas AM, Bassett AH, Cope GH, Le Carpentier JE: Role of growth hormone in the development of experimental renal scarring. Kidney Int 1991, 40(1):29-34.

doi:10.1186/1752-1947-5-400

Cite this article as: Samardzic et al.: Effect of growth hormone

replacement therapy in a boy with Dent's disease: a case report. Journal of Medical Case Reports 2011 5:400.

\section{Submit your next manuscript to BioMed Central} and take full advantage of:

- Convenient online submission

- Thorough peer review

- No space constraints or color figure charges

- Immediate publication on acceptance

- Inclusion in PubMed, CAS, Scopus and Google Scholar

- Research which is freely available for redistribution

Submit your manuscript at www.biomedcentral.com/submit
( Biomed Central 